\title{
Competitive politics, simplified heuristics, and preferences for public goods
}

\section{Journal Article}

Author(s):

Schläpfer, Felix; Schmitt, Marcel; Roschewitz, Anna

Publication date:

2008-04-15

Permanent link:

https://doi.org/10.3929/ethz-a-005717499

\section{Rights / license:}

Creative Commons Attribution-NonCommercial-NoDerivatives 4.0 International

Originally published in:

Ecological Economics 65(3), https://doi.org/10.1016/j.ecolecon.2007.08.008 


\title{
Ecological Economics, in press
}

Section: Analysis

Editor: Cutler J. Cleveland

\section{Competitive politics, simplified heuristics, and preferences for public goods}

\author{
Felix Schläpfer, ${ }^{1, *}$ Marcel Schmitt, ${ }^{2}$ and Anna Roschewitz ${ }^{2}$ \\ ${ }^{1}$ Socioeconomic Institute, University of Zurich, Zurich, Switzerland \\ ${ }^{2}$ Economics Division, Federal Research Institute WSL, Birmensdorf, Switzerland
}

*Corresponding author address: Socioeconomic Institute, University of Zurich, Hottingerstrasse 10, 8032 Zurich, Switzerland. Tel.+411 634 4595, E-mail: felix.schlaepfer@soi.uzh.ch

\begin{abstract}
This paper examines the role of simplified heuristics in the formation of preferences for public goods. Political scientists have suggested that voters use simplified heuristics based on the positions of familiar parties to infer how a proposed policy will affect them and to cast a vote in line with their interests and values. Here, we use a two-stage field-survey experiment to investigate how knowledge of party positions affects policy choices. We followed standard procedures in developing an attribute-based choice experiment on alternative land-use policies in Switzerland. In contrast to the usual formulation, however, the hypothetical costs of the proposed policies were formulated as a percentage change in taxes. The benefit of this formulation relative to the usual absolute money amounts is that the credibility of the (hypothetical) costs for respondents does not depend on respondent income. Furthermore, the formulation allowed us to solicit party positions on the proposed policies. Six out of eight contacted parties provided their positions. We then conducted a split-sample mail survey where we included a table of the party positions with a sub-sample of the questionnaires. We report six main experimental results. (1) The response rate of the survey was unaffected by the party positions. (2) The proportion of nochoice answers was decreased by forty percent relative to the control. (3) The party information significantly affected the choices directly and in interaction with respondents' general attitudes towards public spending for nature and landscape conservation and thus affected the way how
\end{abstract}


individuals mapped from general attitudes to preferences for specific policies. (4) The information interacted with educational level in only eight out of forty choice sets, suggesting that even the more educated relied on simplified heuristics. (5) Respondents who knew the party positions were more sensitive to the tax attribute. (6) For respondents with medium and higher tax bills, the resulting willingness-to-pay estimates were decreased by a factor of two to ten relative to the control. These findings suggest that the party information helped the respondents to articulate more consistent preferences than in the treatment without the party information.

Key words: agriculture, bounded rationality, choice experiment, contingent valuation, landscape, heuristics, information, preference formation, public goods, voting.

JEL catergories: D61, D70, D81, Q26, Q28, Q51 


\section{Introduction}

Research on social psychology and public opinion has identified a number of empirical regularities on how people form preferences in the political and social spheres (Druckman and Lupia, 2000). First, in areas where people do not have significant prior experience, preferences are "constructed" during the decision task itself. The process of preference formation can easily be influenced by contextual factors (Kahneman and Tversky, 1984). Second, social interactions shape decisions. People are often persuaded by individuals they personally interact with and by organizations sharing ideological views and interests (Milgrom and Roberts, 1986; Manski, 2000). In the political arena, such influences affect the decisions on whether and how to vote (Beck et al., 2002). Third, voter awareness of specific issues is quite low and hence susceptibility to persuasion is high (Zaller, 1992). Based on these findings, a growing body of research in economics assumes that individual beliefs and preferences on many issues are flexible, particularly in areas where people do not have significant personal involvement, and that as a consequence people are vulnerable to persuasion and influence (Conlisk, 1996; Murphy and Shleifer, 2004).

For the important empirical context of collective decisions, the current evidence on these regularities rests on observational, correlative studies. Researchers have surveyed voters' knowledge of contextual cues such as party positions in order to explore how this knowledge may have influenced the voting decisions, controlling for other factors such as prior knowledge about the details of the proposition (e.g. Lupia 1994). Unfortunately, the role of the contextual factors cannot be properly identified in these studies since the voters' knowledge is likely to be endogenously determined by individual characteristics that may themselves affect the decision. To cleanly separate the effects of the contextual factors and the individual characteristics it is necessary to conduct an experiment in which important contextual factors are fully controlled. Such a study would allow one to better understand how specific contextual factors shape preferences for public goods in interaction with individual characteristics.

The aim of the present study is to provide such an experiment. We report the results of a factorial experiment investigating how the characteristics of individual voters, of proposed policies and of information environments interact in individual choices about public goods. The contextual factor we examine is the availability of credible information about the positions of large political parties and interest groups. This factor is of particular interest for three reasons. First, research in economics and the political sciences suggests that reputable competing parties 
have an interest to produce reliable signals (Milgrom and Roberts, 1986; Lupia and Matsusaka, 2004). Second, the positions of parties with known ideological orientation are a primary source of information that voters use in collective decisions, while the role of media coverage and interpersonal communications is rather in information transmission (Beck et al. 2002). Third, accessibility of party information is an important factor distinguishing preference formation in voting decisions and stated preference surveys (Schläpfer and Hanley, 2006). The study may thus shed new light on the question why stated preferences may not predict the preferences revealed in collective decisions. We thus examine individual choices about the provision of public goods by respondents with and without access to party positions.

We find that knowledge of party positions affected individual decisions in several important ways. The results experimentally confirm the earlier suggestion by political scientists that voters use simplified heuristics to make decisions in line with their interests and values. The findings suggest that the attention to different information environments may contribute to a better understanding of preferences for public goods in voting decisions and surveys.

The remainder of the paper is organized as follows. The next section provides a brief introduction to related literature. Sections 3 and 4 describe the empirical methods and the results. Section 5 contains a discussion, followed by conclusions.

\section{Background}

People appear to have relatively stable attitudes towards broadly defined classes of public goods and services such as education, public transportation, or the environment. They hold views about whether more, less or the current amount of public money should be spent on policies related to these classes of public goods and services. Such attitudes or tastes can be understood as summary positions (relative to other people's summary positions) that are shaped in the context of real-world debates about specific policy issues belonging to these classes of public goods (Kahneman et al., 1999).

If people also have stable preferences for specific policy proposals that have never been subject to public debate is less clear. In areas where people do not have significant prior experience, preferences appear to be constructed from underlying values (Kahneman and Tversky, 1984). Preference formation is easily influenced by contextual factors (Gregory et al., 1993; Schkade and Payne, 1994; Payne et al., 1999; Clark et al., 2000). Hence, it is not difficult to devise decision settings in which humans fail to retrieve and process preference information 
consistently (Boyle et al., 1994; Hanley and Shogren, 2005). It is a much greater challenge to find out how decision settings can be structured in such ways that humans are capable of making consistent decisions in spite of well-known cognitive limitations. This has become particularly evident from attempts to use surveys to measure preferences for public goods such as the preservation of endangered species or wilderness areas (McFadden, 1999).

However, psychologists and economists have made important progress in understanding why human decisions are often inconsistent. McFadden (1999) notes that "careful attention to the processes that consumers use to define tasks and construct preferences may allow one to look behind the superficial errors to uncover stable principles, attitudes, and preferences upon which a new economic analysis might be built." Psychologists view preferences as constructed from more stable attitudes by a context-dependent process that determines the prominence given to various attitudes and the tradeoffs between them (see Kahneman et al. 1999). According to psychologists, a suitable choice of context may thus help improve the "rationality" of preferences elicited in surveys (Payne et al., 1999).

Political scientists have shown how environmental factors can restore apparently rational decisions in the empirically important context of voting. Voters in referenda use informational "short cuts", in particular information about the positions of trustworthy, knowledgeable individuals or groups with known preferences over outcomes, to infer how a proposition will affect them and to make choices that appear to be consistent with their interests and values (Bowler and Donovan, 1998; Lupia, 1994; Lupia and McCubbins, 1998; Lupia and Matsusaka, 2004). Lupia (1994), for instance, who analyzed a California referendum about complex insurance reform initiatives found that voters who possessed relatively low levels of factual knowledge about the initiatives but could correctly identify the insurance industry's preferences on a particular proposition were much more likely to emulate the behaviour of relatively wellinformed voters on that propositions than similarly uninformed voters who did not know the insurance industry's position.

While the results of these studies are important for understanding voting decisions, they are not suited to properly identify the role of the contextual factors in voting decisions for two reasons. First, in observational studies correlating voting decisions with voters' knowledge of party positions or other contextual factors (controlling for knowledge about the details of the proposition), the effects of knowing the party positions are potentially confounded with effects of individual characteristics. This is because individual knowledge of the party positions is likely to be endogenously determined by individual characteristics that may themselves affect the decision. Second, due to the inherent tendency of the political process to produce policy 
proposals that are near median preferences, the mere fact that a proposal made it to the final decision stage constitutes a contextual cue that can be exploited in simplified heuristics. For instance, green voters may in many cases know how to vote their interests in an open-space preservation initiative without looking at the details of the proposition and without knowledge of party positions. In an observational study this can easily create the illusion that voters possess the cognitive capabilities to independently and reliably process large amounts of information relevant to complex decisions about specific changes in the levels of unfamiliar public goods offered at specified costs.

Hence, to fully isolate the role of context in voting decisions, two conditions must be realized. First, the contextual factors of interest must be experimentally controlled by randomly allocating subjects to the alternative treatments conditions. Second, it is necessary to use random policy proposals that may or may not be similar to the proposals that might be expected to evolve from a typical political process.

In a first experiment following this rationale, Schläpfer and Schmitt (2007) examined effects of simplified heuristics based on knowledge of party positions in a contingent-valuation survey experiment. The present paper extends that research in two important ways. First, the present study is designed in the context of an attribute-based choice-experiment, which is the most popular preference elicitation approach today. More importantly, the present study examines for the first time how the information context interacts with individual characteristics. Specifically, it examines how knowledge about party positions affects environmental decisions by individuals with different attitudes, education, tax burden and urban vs. rural residence.

\section{Methods}

\subsection{Experimental design}

In this study we applied a relatively new variant of stated-preference elicitation techniques, broadly referred to as attribute-based methods (Louviere et al. 2000; Bennett and Blamey 2001; Holmes and Adamowicz, 2003; Holmes and Boyle 2005). In attribute-based stated-preference questions, a policy alternative is decomposed into $k$ singularly and precisely specified attributes, one of which is the bid amount. Experimental design procedures are used to construct alternatives from the attribute set. Respondents are asked to choose one alternative from a choice 
set containing two or more policy alternatives. One of the policy alternatives is typically the status quo. Questions may be posed in the referendum voting format recommended by the NOAA panel (Arrow et al., 1993), but in contrast to many contingent valuation studies, respondents are given a series of choice sets.

The policy alternatives of the present study were structured around alternative land-use patterns for the Swiss Plateau, i.e. the lowlands between the Jura mountain range and the Alps. As in Holmes and Boyle (2005), each choice set consisted of two policy alternatives, one of them representing the status quo. The alternatives were characterized by $n=6$ landscape attributes and a "price" in terms of the tax money required to maintain the landscape pattern through, for instance, land-use incentive schemes. The tax attribute was formulated as a percentage change in the direct taxes on income and wealth. This formulation potentially enhances scenario credibility relative to the standard format with absolute money amounts (see Champ et al. 2002; Flores and Strong, 2007; Schläpfer and Bräuer, 2007), and it allowed us later on to collect party positions on the proposed policies.

The six land uses were 'forest', 'high-intensity grassland', 'crop land', 'low-intensity meadows', 'orchards, hedgerows, and trees', and 'nature reserves'. The six landscape attributes described the extent of the six main land uses as a percentage of the total land surface. Given the current goal to reduce agricultural subsidies in the lowlands, the attribute levels were chosen in such ways that most changes from the status quo would be less expensive, although possibly at the cost of less aesthetic value of the landscape, for instance, due to the spread of forest (Table 1). We framed the choice problem as a referendum in which citizens were asked to vote in favor or against propositions offering alternative land-use policy outcomes.

\section{[Table 1 about here]}

The program Gosset was used to generate the fractional factorial design of the choice experiment (Hardin and Sloane, 2003). Two or three attribute levels were chosen for the individual attributes, depending on whether only linear effects were of interest or both linear and quadratic. We specified an I-optimal design (minimizing the average prediction variance) and a target of 40 policy alternatives, which is sufficient to estimate all main effects and one-way interactions, while still keeping 15 extra design points to further reduce the average prediction variance. To keep the choice tasks manageable, the resulting forty choice sets were allocated to five blocks (different questionnaires) consisting of eight choice sets each. Since the percentages of land in the $n$ different uses must sum to a constant land surface, only $n-1$ land-use attributes were experimentally varied in the factorial design. The level of the remaining attribute (highintensity grassland) was given by the difference between the total undeveloped land, which 
amounted to $74 \%$ of the total land surface, and the sum of the levels of all the other attributes (land uses). As a consequence, each change in a particular land-use type is a change at the expense (or in favour) of the land use represented by the free variable.

In accordance with the aims of the study, we added two additional features to the standard choice experiment design. First, we stratified our sample to be able to identify any variation in responses among the urban, periurban and rural sub-populations. We chose a study region near Zurich that appeared to be topographically representative of the Swiss Plateau and selected one urban (Zurich), two periurban (Faellanden and Greifensee) and two rural (Baeretswil and Grueningen) local jurisdictions (municipalities) from which to recruit potential respondents. These municipalities were selected to represent three strongly contrasting (while still sufficiently large) sub-populations in terms of income, agricultural employment, and voting behaviour in past land-use related referendum decisions (Table 2).

[Table 2 about here]

Second, we added the voting recommendations treatment (see Survey procedures) as another orthogonal factor. Thus, one half of the potential respondents of each population stratum were supplied with the party information, while the other half served as the control group. The design of the experimental extension of the basic choice experiment (with sample sizes for each treatment $\times$ stratum combination) is presented in Table 3 . The five different questionnaire versions (choice set blocks) were replicated within these design cells.

\section{[Table 3 about here]}

\subsection{Survey procedures}

We initially determined a set of land-use attributes to represent useful descriptors of the landscape. Status quo levels of the attributes were collected from the Swiss land-use Statistics (FSO, 1992-97), the Swiss Federal Office of Agriculture, and the Canton of Zurich Office for Nature and Landscape. Based on a sequence of focus group sessions with representatives of the Federal Office of Agriculture, the Canton of Zurich Office for Nature and Landscape and two regional non-governmental organizations active in regional nature conservation, the set of attributes was slightly modified and realistic, policy-relevant attribute levels were determined. About 15 selected individuals were then asked to complete the questionnaire and were later interviewed about their experience with the task. Finally, a mail pre-test with $n=70$ addresses (yielding about 50 responses) was conducted to check understanding and response distributions. Ten respondents of this pre-test were individually contacted by phone and asked about their 
experience and satisfaction with the content of and the illustrations used in the questionnaire. For one attribute, attribute levels were changed as a consequence of the pre-test results.

The questionnaire consisted of five parts. In the first part, respondents were asked about their general attitudes towards the landscape and the role of the government in resource and landscape protection in agricultural areas. In the second part, the individual landscape components, forest, high-intensity grassland, crop land, low-intensity meadows, orchards, hedgerows, and trees, and nature reserves and their functions, were briefly described individually and illustrated with three or four photographs. Third, the respondents were introduced to the task of choosing their preferred policy alternative (landscape) in sets of two possible future landscapes in the Canton of Zurich, taking into account their tax payment. This text was accompanied by a pie chart showing the current allocation of land to the six different uses in the Canton of Zurich and by an example of a choice set. The fourth part contained the choice sets, numbered 1 through 8 . Landscape attribute levels were illustrated in horizontal bar charts and the policy alternatives were labelled "Landscape A (Alternative)" and "Landscape B (Status Quo)". The tax-bill attribute was given in words such as " 2 percent less (corresponding in my case to CHF...)" or "unchanged". A pictogram of a bill was inserted near the words "tax bill" in order to match the high visibility of the land-use attributes illustrated in the bar charts (Appendix, Fig. 1). The respondents could choose among A, B, and "no choice". The choice sets were followed by a question about how certain respondents felt about their choices on a four-level ordinal scale. The final section contained six questions concerning socio-economic characteristics. Instead of the usual income question we asked respondents to specify how much (direct) tax they had paid in total in the previous year (to the nearest 500 SFR). We chose not to ask the respondents about their political position with respect to political parties or interest groups (see below) because we expected that such questions might interact with the valuation questions in undesired and uncontrolled ways.

The national offices of political parties and important interest groups concerned with land-use issues were then contacted by phone and asked if they would be willing to provide their positions or choice recommendations for the 40 choice sets of the survey. Six of the eight parties and interest groups we contacted agreed to participate. The final questionnaire with all 40 choice sets was sent out to these organizations by mail. In most cases, specialized policy staff took charge of the task. The resulting choice recommendations spanned a wide spectrum of parties and relevant interest groups, as intended for the purposes of the experiment. Recommendations were obtained from the following organizations: People's Party (SVP, right-wing), Christian Democrats (CVP, center), Social Democrats (SP, left-wing), Swiss Farmers Union, Swiss 
Consumer Forum (large consumer organization), and Pro Natura (largest NGO in Swiss nature conservation). For each block of the experimental design, a sheet with the recommendations was then printed and included as a supplement in the questionnaires of the INFO subsample. The recommendations (choices A or B) were presented in tabular form, with questions one through eight in rows and parties/interest groups in columns. The names and functions of the organizations' representatives who had provided the recommendations were listed below the table, and those two parties who did not provide their positions were also noted on the information sheet to make the party involvement as transparent as possible (Appendix, Fig. 2). The frequencies of A (alternative) and B (status quo) recommendations and of "no recommendation" for each party and interest group are listed in Table 4.

[Table 4 about here]

Potential respondents to the mail survey were recruited by telephone. The target individuals were selected in a two-stage process to obtain a sample that corresponded well with the structure of the sampled population. First, random samples were drawn from the list of telephone numbers in the survey areas. The household structure was then surveyed, yielding number, age, and gender of all potential respondents in the household (citizens with the right to vote). A random sample of individuals was then drawn from the potential target members of the households. Households were contacted five times (on different days) before target respondents were replaced. A computer-assisted algorithm for selecting replacements ensured that the age and sex distribution in the sample remained close to census distributions. Within a few days, the questionnaires were sent by mail to the persons who had agreed to participate in the survey. About two weeks after they received the questionnaires, the participants were sent a short letter reminding them of the deadline. A more detailed account of the survey process is available in Schmitt et al. (2005). 


\subsection{Hypotheses}

The experimental design permits us to test a number of hypotheses regarding the effects of the party information on stated preferences for public goods. First, we used Chi-square independence tests to examine whether the information treatment affected (i) the questionnaire return rate, (ii) the frequency of the four response options (alternative, status quo, "no choice" and item non-response) and the (iii) frequency of "no-choice" or item non-response in the valuation questions (choice sets), and (iv) the self-reported levels of certainty about the given responses:

$\boldsymbol{H}_{1}$ : Freq(non-response) $)_{\text {Control }} \neq$ Freq(non-response) $)_{\text {IS }}$

$\boldsymbol{H}_{2}$ : Freq(response options) $)_{\text {Control }} \neq$ Freq(response options) $)_{I S}$

$\boldsymbol{H}_{3}$ : Freq("no choice" or non-response) $)_{\text {control }} \neq$ Freq("no choice" or non-response) $)_{\text {IS }}$

$\boldsymbol{H}_{4}$ : Freq(certainty levels $\left.1-4\right)_{\text {Control }} \neq$ Freq(certainty levels $\left.1-4\right)_{\text {IS }}$

Second, we used random-effects Probit regression to estimate choice models of the binary (alternative vs. status quo) responses to the choice sets for each of the INFO $\times$ population subsamples. The random-effects model, as implemented in Limdep 7 (Greene, 1998), was used to account for preference heterogeneity and correlation among the multiple responses by individual respondents (see e.g. Holmes and Boyle, 2005). Furthermore, we computed benefit estimates for the proposed land-use changes. Based on the disaggregated estimates, we explored if the information shortcuts improved the correspondence of the benefit estimates with the same populations' voting behaviour in recent voting decisions about agri-environmental policy and landscape protection financing (see 'Experimental design').

To test the main and interactive effects of the INFO treatment we pooled the data of the subsamples to estimate models including as explanatory variables all main effects (INFO, population dummies and attributes), the two-way interactions (INFO $\times$ population, INFO $\times$ attribute, population $\times$ attribute), and the tree-way interactions (INFO $\times$ population $\times$ attribute). This model encompasses the following hypothesis tests (of linear restrictions on the individual $\beta$ coefficients):

$$
\begin{aligned}
& \boldsymbol{H}_{5}: \beta_{\mathrm{INFO} \times \text { pop }} \neq 0 \\
& \boldsymbol{H}_{6}: \beta_{\mathrm{INFO} \times \text { attributes }} \neq 0 \\
& \boldsymbol{H}_{7}: \beta_{\mathrm{INFO} \times \text { pop } \times \text { attributes }} \neq 0
\end{aligned}
$$

Third, a simple Probit regression is used to test a series of hypotheses about the effects of the INFO treatment and its interaction with the individual-level characteristics "attitude" and 
"educational level" in each of the 40 choice sets. The selection of attitude and education was guided by previous research in the political sciences. Individual attitude is relevant because political scientist have argued that party positions may enable relatively uninformed voters to cast a vote in line with their interests and values (Lupia, 1994). Significant INFO $\times$ attitude interactions would suggest that the contextual information transformed the relationship between choices and underlying attitudes and values. Educational level is of interest because contextual information may be expected to affect voters differently across different levels of political knowledge.

A variable "Attitude" was coded based on the responses to the question "Should the public spend rather more or rather less money for the protection and management of nature and landscape?" The response options were: "more", "somewhat more", "the same as today", "somewhat less", "less" and "don't know". The question is not as ad hoc as might seem. A qualitative question about the direction of the respondents' preferred amount of public expenditure for a broader class of public goods is something about which respondents may have consistent preferences because the question relates to the familiar issue of marginal changes of expenditure for an entire class of public goods from the status quo (see Background). Bergstrom et al. (1982) used the same question format arguing that it poses relatively low cognitive demands on the respondents. A variable "Education" was defined based on a standard question about "highest educational achievement". The coding is from 1 for "mandatory schooling" to 5 for "university degree" (see Table 6). For each of the 40 choice sets we thus estimate the Probit model:

$$
\operatorname{Pr}[\text { yes }]=\Phi\left(\alpha+\beta_{1} \text { INFO }_{i}+\beta_{2} \text { INFO }_{i} \times \text { Attitude }_{i}+\beta_{2} \text { INFO }_{i} \times \text { Education }_{i}\right)
$$

The specific hypotheses about the effects of the information treatment and its interaction with the individual characteristics are tested as linear restrictions of the model. The (alternative) hypotheses are:

$$
\begin{aligned}
& \boldsymbol{H}_{\mathbf{8}}: \beta_{1} \neq 0 \\
& \boldsymbol{H}_{9}: \beta_{2} \neq 0 \\
& \boldsymbol{H}_{\mathbf{1 0}}: \beta_{3} \neq 0 .
\end{aligned}
$$

Forth, we estimated choice models of the binary responses to the choice sets for the four INFO $\times$ Attitude subsamples, and we used the estimates to compute benefit estimates for the proposed land-use changes. A model of the pooled choice sets was used to test the effects of the 
two-and three-way interactions of INFO with Attitude the policy attributes as linear restrictions on the respective terms in the regression:

$$
\begin{aligned}
& \boldsymbol{H}_{11}: b_{\mathrm{INFO} \times a \text { attribute }} \neq 0, \\
& \boldsymbol{H}_{12}: b_{\mathrm{INFO} \times \text { Attitudexattributes }} \neq 0 .
\end{aligned}
$$

Space limitations do not allow us to explain expectations concerning the effects each of the many variables in these models. However, at a more general level, the null hypothesis is simple. The prediction of the standard economic model is that individual choices are not affected by the INFO treatment (including by any interactions of INFO with other variables).

\section{Results}

\subsection{Response rates}

The response rate for the questionnaires was 69.8 percent. Due to variation in participation rates, the number of returned questionnaires was highest in the rural population and lowest in the urban population (Table 5).

\section{[Table 5 about here]}

There was no effect of the INFO treatment on questionnaire return rates (see Table 3). The null hypothesis corresponding to $\boldsymbol{H}_{\mathbf{1}}$ - no effect of INFO on participation rate - cannot be rejected. Chi-square independence and t-tests revealed no differences in socioeconomic characteristics between the respondents allocated to the INFO and the control treatments (Table 6).

\section{[Table 6 about here]}

\subsection{Effects on the frequency of response categories}

The 546 survey respondents delivered a total of 3853 "Landscape A" (alternative) or "Landscape B" (status quo) choices. These choices were evenly distributed between the alternative (49.7 percent) and the status quo (50.3 percent). Rates of approval of the alternative across the 40 choice sets varied between 9 percent and 82 percent. There were 218 "no choice" and 297 itemnon-response answers. The frequency of these choices in the six subsamples is presented in Table 7. For the pooled populations, the INFO treatment affected the frequencies of the four response options $\left(\boldsymbol{H}_{2}\right)$ and reduced the frequency of "no choice" or item non-response from 14.5 percent in the control to 8.9 percent under the INFO treatment (Table 7, last column) $\left(\boldsymbol{H}_{3}\right)$. The 
distribution of self-reported levels of certainty about the given responses $\left(\boldsymbol{H}_{4}\right)$ did not significantly differ between treatments $\left(\chi_{<3>}^{2}=1.45 ; p=0.69\right.$ for the pooled data).

\section{[Table 7 about here]}

\subsection{Effects of the party information on the valuation of policy attributes - by population}

Table 8 presents the random-effects Probit models of the binary (alternative vs. status-quo) policy choices and WTP estimates for the six INFO $\times$ population subsamples. Under the control treatment, the cost attribute DTAX was non-significant in all three population subsamples. Under the INFO treatment, DTAX became significant in the periurban and rural populations and marginally significant in the urban subsample $(t=1.56, p=0.12)$. In models with the pooled population subsamples, the INFO treatment decreased the mean benefit estimates by between 30 percent (for TREE) and 47 percent (for RESE).

WTP estimates were derived by computing the ratio of the coefficient estimate on the attribute of interest divided by the coefficient estimate on the tax attribute, i.e., the marginal rate of substitution between the attribute and the tax change (Table 8, columns headed "WTP"). For interpreting the attribute effects, it is important to notice that all attribute coefficients and benefit estimates refer to percentage land use changes in favour/at the expense of land in the omitted category high-input grassland (see Experimental design).

The decreased WTP in general, and the decreased WTP for nature reserves among the rural population in particular (cf. Table 2), suggest that the INFO treatment promoted consistent choices about the policy alternatives.

\section{[Table 8 about here]}

The tests of our hypotheses about the effects of INFO on the binary responses (hypotheses $\boldsymbol{H}_{5}$ through $\boldsymbol{H}_{7}$ ) are encompassed by the model with the pooled samples that includes the interactions of the attributes with the additional design factors as additional explanatory variables. The complete model estimates are available on request. The significant terms (with coefficient signs) in the model are CROP $(+)$, LOWI $(+)$, INFO $\times$ Rural (positive effect relative to Urban reference), $\mathrm{CROP} \times$ Periurban $(+), \mathrm{CROP} \times \operatorname{Rural}(+), \mathrm{CROP} \times \operatorname{INFO}(+)$, and $\mathrm{CROP} \times \mathrm{INFO} \times$ Periurban $(-)$. Hence, only the effect of CROP - the most highly significant attribute in the subsamples (see Table 8) - was consistently affected by the INFO treatment. The coefficient signs agree with expectations. They suggest that rural respondents valued the extent of cropped land more highly relative to the urban and periurban respondents, and that this effect 
was enhanced by the INFO treatment. Restrictions on entire sets of variables were not significant. Wald tests yielded the following results: for $\beta_{\text {INFO aattributes }}=0, \chi^{2}=9.98(p=0.13)$; for $\beta_{\text {attributes } \times \text { Periurban } \times I S}=0, \chi^{2}=9.74(p=0.14)$; and for $\beta_{\text {attributes } \times \text { Rural } \times I S}=0, \chi^{2}=5.67(p=0.46)$.

\subsection{Interactions of the party information with respondent attitude and education}

Table 9 (upper part) shows the experimental design for the analysis of the interaction between the INFO treatment and individual attitudes towards public spending for nature and landscape conservation.

\section{[Table 9 about here]}

Table 10 presents the Probit estimates (Equation 1 in section 3.3) for the 40 individual choice sets, providing the tests of hypotheses $\boldsymbol{H}_{\boldsymbol{8}}$, through $\boldsymbol{H}_{10}$. The party information significantly affected the decisions in 24 out of the 40 choice sets either directly or through the interaction with individual-level characteristics. The INFO treatment significantly changed the effect of Attitude (INFO $\times$ Attitude) in 19 choices sets, indicating that the information context transformed the mapping from general attitudes to dollar preferences for specific policies. Furthermore, INFO interacted with Education in only 8 choice sets, which suggests that the use of simplified heuristics was not limited to respondents with low levels of education.

\section{[Table 10 about here]}

\subsection{Effects of the party information on the valuation of policy attributes - by attitude}

Table 11 presents the random-effects Probit estimates of the attribute-based referendum model for the four INFO $\times$ Attitude subsamples. The WTP estimates were derived as in Table 8 . While these models do yet provide a test of whether the INFO $\times$ Attitude interaction systematically affected the valuation of the policy attributes, they provide a descriptive overview of the data and facilitate the interpretation of the following model with the pooled subsamples and including the interactions terms (see Table 12). Among the respondents with a taste for increasing public spending for landscape amenities management (Attitude $=1$ ), the party information decreased the mean benefit estimates for CROP by about 58 percent, for LOWI by 14 percent, for TREE by 70 percent and for RESE by 58 percent. The INFO treatment thus decreased the WTP estimates on average by about 50 percent. These results indicate that individuals who are generally supportive of nature and landscape protection formed different preferences for the land-use attributes when the party positions were available. Among the remaining respondents, the party positions 
decreased WTP for RESE by 46 percent. Estimates for the remaining attributes are not reliable due to non-significant coefficients in the choice models of the respective subsamples.

\section{[Table 11 about here]}

Two further patterns which parallel those described in Section 4.3 suggest that the party information enhanced the validity of the choices. First, the tax change specified in the choice sets (DTAX) was only weakly significant or even insignificant in the respondent subsamples which did not have access to the party positions. In the subsamples with party information, the tax change was significant at $\mathrm{p}<0.05$. Second, the amount of land allocated to uses generally regarded as landscape amenities (LOWI and RESE) was valued even by respondents with negative or neutral attitudes towards public spending for nature and landscape. This counterintuitive result disappeared when these respondents had access to the party information (Table 11, last column; LOWI, ORCH and RESE non-significant).

Table 12 presents the random-effects Probit model of the pooled samples, encompassing the tests of hypotheses $\boldsymbol{H}_{11}$ and $\boldsymbol{H}_{12}$. Regarding hypothesis $\boldsymbol{H}_{11}$, the INFO treatment interacted significantly (positively) with TREE. Of particular interest are the three-way attribute $\times \mathrm{INFO} \times$ Attitude interactions $\left(\boldsymbol{H}_{12}\right)$. In the regression framework these terms essentially test if the party information had an influence on how individuals mapped from attitudes to dollar preferences for landscape attributes. The information treatment interacted significantly with two of the three-way interaction terms, LOWI $\times$ INFO $\times$ Additude and the TREE $\times I N F O \times$ Attitude.

\section{[Table 12 about here]}

Lacking clear-cut theoretical expectations on the direction of the Attitude effect in these models it is difficult to interpret the individual parameter estimates of this model in detail. Instead, we used Wald tests to examine if the interaction terms involving INFO are jointly significant in the model. The six attribute $\times$ INFO interactions are jointly significant at the 10 percent level $\left(\chi^{2}=11.2 ; p=0.082\right)$. The six attribute $\times$ INFO $\times$ Attitude interactions and the twelve terms together are marginally significant $\left(\chi^{2}=9.52, \mathrm{p}=0.146\right.$ and $\chi^{2}=17.6, \mathrm{p}=0.128$, respectively). Adding to this the results presented in Table 11 the more general lesson is clear. Knowledge of party positions itself and in interaction with respondent attitudes influenced the valuation of policy attributes. In other words, the economic preferences for the public good were driven by the interaction of (i) the public good attributes, (ii) the attitude towards the broader class of public good to which the proposed policies belong, and (iii) the party information relating to the specific policy alternatives. The present analyses thus pinpoint the role of credible party and interest group positions on which cognitively limited respondents rely in their decisions about public goods. 
4.6 Effects of the party information on the valuation of policy attributes - by tax amounts

Given that our experiment formulated the costs of the proposed policies as a percentage change in the tax bills, it is also of interest to examine choice models for respondent groups with different (lower vs. higher) tax bills. As in the analysis of choices for respondents with different attitudes we stratified the sample, but this time according to three tax bill categories (see Table 9, lower part). The cut-off levels were again chosen to yield about equal sample sizes in the categories.

Table 13 presents the random-effects Probit estimates of the attribute based referendum model for the six INFO $\times$ Tax bill subsamples. The WTP estimates were derived as in Table 8 and 11. The tax attribute was non-significant in all subsamples without the party information. Among the subsamples with party information only the subsample of respondents with low tax bills (taxes below 4000 CHF per year) was insensitive to the costs. The medium and high tax-bill groups yielded significant coefficient estimates in spite of the limited sample size. The WTP estimates for these samples were decreased by a factor of about 2 to 10 compared with the samples without the party information. Hence, at least for the medium and high tax bills, these analyses again suggest that the INFO treatment promoted realistic and consistent choices about the policy alternatives.

\section{[Table 13 about here]}

\section{Discussion}

Political scientists have suggested that voters in public referenda may rationally use information short cuts such as party positions to "vote their interests" in spite of limited factual knowledge about the propositions. Here, we examined how access to credible party positions affects individual choices about complex public goods in an environmental valuation context. We found that offering information about the positions of political parties and interest groups to the respondents in a referendum choice experiment affected stated choices about public goods in several ways. Relative to our control, the party information reduced the frequency of non-usable responses, it decreased the implicit benefit estimates for the proposed policies especially among respondents with medium to high tax bills, and it transformed the mapping from general attitudes 
towards public spending for nature and landscape conservation to preferences for specific policies. Several aspects of these results deserve further discussion.

As in the related political science literature, it is difficult to establish if the party information improved the quality of the decisions. We do not have actual voting decisions on the same issue available as a basis for assessing the external validity of the survey responses and the effects of the information treatment upon this quality (cf. Schläpfer et al., 2005). However, the result that the information treatment tended to enhance the respondents' sensitivity to the (tax) price and hence decreased the WTP estimates lends support to the interpretation that the information treatment enhanced the validity of the survey responses. To compare, Macmillan et al. (2002) who examine the effect of allowing contingent valuation (CV) respondents to discuss the choice issue before giving their responses, find that WTP under the discussion treatment was about seventy percent lower than in the control, which was a standard interview.

The magnitude of the treatment effects is likely to be specific to the particular experimental protocol and policy propositions. As mentioned previously, the cost attribute was specified as a percentage change in the annual tax bill. This was a precondition for interest groups to be able to provide voter recommendations. However, recent work by Green et al. (1998), Champ et al. (2002), Schläpfer and Bräuer (2007), and Flores and Strong (2007) suggests that this formulation also increases the credibility of the valuation questions because the randomly assigned (tax) prices are less likely to conflict with expectations of the personal costs if the policy is actually implemented. These authors have noted that typical variations of randomly assigned cost figures between $1 \$$ and $500 \$$ or more may undermine the credibility of the policy scenarios and offer opportunities for strategic answering. Compared with standard formats where the cost attribute is specified in absolute money units, the enhanced credibility of the alternatives may thus have promoted consistent responses also in our baseline (control) treatment.

The approach taken in the present study suggests a novel solution to the problem of providing "adequate" information in stated preference surveys. The NOAA panel report recognizes that problem in stating (Arrow et al., 1993): "Since the design of the CV survey can have a substantial effect on the responses, it is desirable that - if possible - critical features be pre-approved by both sides [...]" (p. 4614). To our knowledge there has not been any research in the direction of this particular recommendation of the NOAA panel. The implicit pre-approval of the survey design by the parties providing their positions is similar to what the NOAA panel suggests. Moreover, by introducing elements of an open, competitive political information environment, the approach to some extent eliminates the problematic information monopoly of the survey researcher. Finally, obtaining party positions from diverse political parties and interest 
groups requires a careful and balanced presentation of the information in the first place. The increased publicity of the survey process may operate as an incentive for researchers to develop high-quality survey instruments and for reputable parties to provide carefully considered, credible positions.

Our experiment fills an important gap between the correlative field studies by political scientists (Lupia, 1994; Bowler and Donovan, 1998; Lupia and Matsusaka, 2004; Druckman 2004), theoretical and experimental work on bounded rationality (Conlisk 1996; Ariely et al. 2003; Frey and Eichenberger, 1994; McFadden, 1999; Payne et al., 1999; Camerer, 1995; Slembeck and Tyran, 2004; Vatn, 2004; Gowdy, 2004; Camerer and Fehr, 2006) and recent experiments on the role of social interactions in surveys of stated preferences for public goods (MacMillan et al., 2002; List et al., 2004; Alvarez-Farizo and Hanley, 2006, Alvarez-Farizo et al., 2007). Our experiment makes the previous findings fruitful for applied valuation research. Although we do not know which particular recommendations were followed by which respondents, the aggregate patterns support the conclusion that the positions of competing parties play a central role in consistent individual decisions about public goods. The study demonstrates that surveys that provide information about credible party positions are a feasible alternative approach to survey-based preferences elicitation.

\section{Conclusions}

Our study is the first to cleanly identify the interactive effects of information context, policy characteristics, and individual characteristics in decisions about public goods. We experimentally confirmed the political scientists' interpretation that preferences for unfamiliar public goods are constructed from underlying attitudes and values using simplified heuristics based on the positions of familiar parties and interest groups with known ideological orientation (Lupia and Matsusaka, 2004). The findings suggest that economic models of voting are incomplete in the sense that they do not explicitly account for the role of contextual information generated by political institutions such as political parties and public debate. This model incompleteness is potentially problematic in situations where access to the positions of credible parties cannot be taken for granted, as in voting decisions in less developed democracies or in surveys.

The findings are also potentially relevant for future research on stated preferences for public goods as they suggest that many survey respondents, like voters in referenda, may not be able to make reasoned decisions without access to contextual signals. Stated preferences with 
access to information cues from reputable competing parties and interest groups are an alternative approach to preference elicitation. The approach combines the advantages of a fully controlled good with an information context that is similar to the information context of an actual referendum. Furthermore, the approach at least partly eliminates the problematic information monopoly of the survey researcher. The approach can thus be seen as a promising avenue among recent attempts to widen perspectives in the valuation of public goods (Frey and Stutzer, 2002; van Praag and Baarsma, 2005).

There is much more to be learned about the role of simplified heuristics in decisions about public goods. Potential topics include experiments with different types of contextual cues and in different political systems, studies on individual updating behaviour when the party information becomes available, or experiments on the role of reputation effects for the credibility and use of contextual cues. Such experiments would be most interesting and relevant to environmental valuation research if they involved field samples and actual policy issues.

\section{Acknowledgements}

We would like to thank our colleagues who commented on preliminary versions of the survey questionnaire, Vic Adamowicz for advice concerning experimental design, Rainer Winkelmann and Bernhard Schmid for statistical advice, and the Canton of Zurich Office for Landscape and Nature and Office for Statistics for providing data. We are grateful to Bruno Frey, Jason Shogren, Nick Flores, James Druckman, two anonymous reviewers, participants at the EAERE conference 2004 and participants of research seminars at the University of Zurich, at the ETH Zurich and at the University of Colorado for valuable comments. Financial support from the ETH Zurich Department of Agricultural Economics, the Swiss Federal Research Institute WSL, the Canton of Zurich Office for Landscape and Nature, and the Swiss Federal Office for Agriculture is gratefully acknowledged. 


\section{References}

Alvarez-Farizo, B. and Hanley, N., 2006. Improving the process of valuing non-market benefits: combining citizens' juries with choice modelling. Land Economics 82 (3), 465-478.

Alvarez-Farizo, B., Hanley, N., Barberan, R. and Lazaro, A., 2007. Choice modeling at the "market stall": Individual versus collective interest in environmental valuation. Ecological Economics 60 (4), 743-751.

Ariely, D., Loewenstein, G. and Prelec, D., 2003. "Coherent arbitrariness": stable demand curves without stable preferences. Quarterly Journal of Economics 118(1), 73-105.

Arrow, K., Solow, R.., Portney, P. R., Leamer, E. E., Radner, R. and Schuman, H., 1993. Report of the NOAA Panel on contingent valuation. Federal Register 58 (10), 4601-4644.

Beck, P. A., Dalton, R. J., Greene, S. and Huckfeldt, R., 2002. The social calculus of voting: Interpersonal, media, and organizational influences on presidential choices. American Political Science Review 96 (1), 57-73.

Bennett, J. and Blamey, R., 2001, The Choice Modelling Approach to Environmental Valuation. Edward Elgar, Northhampton, MA.

Bergstrom, T. C., Rubinfeld, D. L. and Shapiro, P., 1982. Micro-based estimates of demand functions. Econometrica 50, 1183-1205.

Bowler, S. and Donovan, T., 1998, Demanding choices: opinion, voting, and direct democracy. University of Michigan Press, Ann Arbor.

Boyle, K. J., Desvousges, W. H., Johnson, F. R., Dunford, R. W. and Hudson, S. P., 1994. An investigation of part - whole biases in contingent-valuation studies. Journal of Environmental Economics and Management 27 (1), 64-83.

Camerer, C., 1995, Individual decision making. In: J. Kagel and A. Roth (Eds.), Handbook of Experimental Economics. Princeton University Press, Princeton, NJ, pp. 587-703.

Camerer, C. and Fehr, E., 2006. When does "economic man" dominate social behavior? Science, 311 (5757), 46-52.

Champ, P. A., Flores, N. E., Brown, T. C. and Chivers, J., 2002. Contingent valuation and incentives. Land Economics 78 (4), 591-604.

Clark, J., Burgess, J. and Harrison, C. M., 2000. "I struggled with this money business": respondents' perspectives on contingent valuation. Ecological Economics 33 (1), 45-62.

Conlisk, 1996. Why bounded rationality. Journal of Economic Literature 34, 669-700.

COS, 1999. Die Zürcher Landwirtschaft wandelt sich, Canton of Zurich Office of Statistics, Zürich. 
Executive Council, 1995. Beschluss des Regierungsrates über die Ergebnisse der eidgenössischen Volksabstimmung vom 12. März. Zürcher Amtsblatt, 633-659.

Executive Council, 1996a. Beschluss des Regierungsrates über die Ergebnisse der eidgenössischen Volksabstimmung vom 9. Juni. Zürcher Amtsblatt, 993-1007.

Executive Council, 1996b. Beschluss des Regierungsrates über die Ergebnisse der kantonalen Volksabstimmung vom 22. September. Zürcher Amtsblatt.

Druckman, J. N. and Lupia, A., 2000. Preference formation. Annual Review of Political Science $3,1-24$.

Druckman, J. N., 2004. Political preference formation: competition, deliberation and the (ir)relevance of framing effects. American Political Science Review 98 (4), 671-686.

Flores, N. E. and Strong, A., 2007. Cost credibility and the stated preference analysis of public goods. Resource and Energy Economics, 29 (3), 195-205.

Frey, B. S. and Eichenberger, R., 1994. Economic incentives transform psychological anomalies. Journal of Economic Behavior \& Organization 23 (2), 215-234.

Frey, B. S. and Stutzer, A., 2002. What can economists learn from happiness research? Journal of Economic Literature 40 (2), 402-435.

FSO, 1992-97. GEOSTAT, Land-use statistics 1992/97. Federal Office of Statistics, Neuchatel, Switzerland.

Gowdy, J. M., 2004. The revolution in welfare economics and its implications for environmental valuation and policy. Land Economics 80(2), 239-257.

Green, D., Jacowitz, K. E., Kahneman, D. and McFadden, D., 1998. Referendum contingent valuation, anchoring, and willingness to pay for public goods. Resource and Energy Economics 20 (2), 85-116.

Greene, W., 1998, Limdep Version 7.0. User's Manual. Econometric Software, Inc., Plainview, NY.

Gregory, R., Lichtenstein, S. and Slovic, P., 1993. Valuing environmental resources - a constructive approach. Journal of Risk and Uncertainty 7 (2), 177-197.

Hanley, N. and Shogren, J., 2005. Is cost-benefit analysis anomaly-proof? Environmental \& Resource Economics 32, 13-34.

Hardin, R.H. and Sloane, N.J.A., 2003. Operating Manual for Gosset: A General-Purpose Program for Constructing Experimental Designs. Statistics Research Report, AT\&T Bell Laboratories, Murray Hill, NJ. 
Holmes, T. P. and Adamowicz, W.L., 2003, Attribute-based methods. In: T. Brown, K. J. Boyle and P. Champ (Eds.), A Primer on Non-Market Valuation. Kluwer, Dordrecht, The Netherlands.

Holmes, T. P. and Boyle, K. J., 2005, Dynamic learning and context-dependence in sequential, attribute-based, stated-preference valuation questions. Land Economics 81(1), 114-126.

Kahneman, D., Ritov, I. and Schkade, D. A., 1999. Economic preferences or attitude expressions?: an analysis of dollar responses to public issues. Journal of Risk and Uncertainty 19 (1-3), 203-235.

Kahneman, D. and Tversky, A., 1984. Choices, values, and frames. American Psychologist, 39, 341-350.

List, J. A., Berrens, R. P., Bohara, A. K. and Kerkvliet, J., 2004. Examining the role of social isolation on stated preferences. American Economic Review 94 (3), 741-752.

Louviere, J.J., Hensher, D.A. and Swait, J.D., 2000, Stated Choice Methods: Analysis and Applications. Cambridge University Press, New York.

Lupia, A., 1994. Shortcuts versus encyclopedias - information and voting- behavior in California insurance reform elections. American Political Science Review 88 (1), 63-76.

Lupia, A. and Matsusaka, J. G., 2004. Direct democracy: new approaches to old questions. Annual Review of Political Science 7, 463-482.

Lupia, A. and McCubbins, M. D., 1998, The Democratic Dilemma: Can Citizens Learn What They Need to Know? Cambridge University Press, New York.

Macmillan, D. C., Philip, L., Hanley, N. and Alvarez-Farizo, B., 2002. Valuing the non-market benefits of wild goose conservation: a comparison of interview and group-based approaches. Ecological Economics 43 (1), 49-59.

Manski, C. F., 2000. Economic analysis of social interactions. Journal of Economic Perspectives $14(3), 115-136$.

McFadden, D., 1999. Rationality for economists? Journal of Risk and Uncertainty, 19 (1-3), 73105.

Milgrom, P. and Roberts, J., 1986. Relying on the information of interested parties. Rand Journal of Economics 17, 18-32.

Murphy, M. and Shleifer, A., 2004. Persuasion in politics. American Economic Review 94, 435439.

Payne, J. W., Bettman, J. R. and Schkade, D. A., 1999. Measuring constructed preferences: towards a building code. Journal of Risk and Uncertainty 19 (1-3), 243-270. 
Schkade, D. A. and Payne, J. W., 1994. How people respond to contingent valuation questions a verbal protocol analysis of willingness-to-pay for an environmental regulation. Journal of Environmental Economics and Management 26 (1), 88-109.

Schläpfer, F. and Bräuer, I, 2007. Theoretical incentive properties of contingent valuation questions: do they matter in the field. Ecological Economics 62 (3-4), 451-460.

Schläpfer, F. and Hanley, N., 2003. Do local landscape patterns affect the demand for landscape amenities protection? Journal of Agricultural Economics 54 (1), 21-34.

Schläpfer, F., Deacon, R. T. and Hanley, N., 2005. A note on the measurement of stated willingness to pay for public goods. Kyklos 58 (1), 145-152.

Schläpfer, F. and Hanley, N., 2006. Contingent valuation and collective choice. Kyklos 59 (1), 115-135.

Schläpfer, F. and Schmitt, M., 2007. Anchors, endorsements, and preferences: a field experiment. Resource and Energy Economics, 29 (3), 229-243.

Schmitt, M., F., Schläpfer and Roschewitz, A., 2005. Bewertung von Landschaftsveränderungen im Schweizer Mittelland aus Sicht der Bevölkerung, Forschungsanstalt für Wald, Schnee und Landschaft WSL, Birmensdorf, Switzerland.

Slembeck, T. and Tyran, J. R., 2004. Do institutions promote rationality? An experimental study of the three-door anomaly. Journal of Economic Behavior \& Organization 54 (3), 337350.

van Praag, B. M. S. and Baarsma, B. E., 2005. Using happiness surveys to value intangibles: The case of airport noise. Economic Journal 115, 224-246.

Vatn, A., 2004. Environmental valuation and rationality. Land Economics 80 (1), 1-18.

Zaller, J., 1992, The nature and origins of mass opinion. Cambridge University Press, Cambridge, UK. 
Table 1. Attribute definitions and levels

\begin{tabular}{|c|c|c|}
\hline Variable name & Attribute definition $^{\mathrm{a}}$ & Levels $^{b}$ \\
\hline FORE & Forest land $(\%)$ & $\mathbf{2 8}, 30,32$ \\
\hline$(\ldots)^{\mathrm{c}}$ & High-input grassland (\%) & $\ldots 20 \ldots$ \\
\hline CROP & Field crops $(\%)$ & $10,14, \mathbf{1 8}$ \\
\hline LOWI & Low-input grassland $(\%)$ & 4,6 \\
\hline TREE & Field hedges, field trees, traditional orchards (\%) & $3,4,5$ \\
\hline RESE & Nature reserves $(\%)$ & 1,2 \\
\hline DTAX & Change of tax bill (\%) & $-2,-1,0$ \\
\hline
\end{tabular}

${ }^{\mathrm{a}}$ Land area is expressed relative to the total land surface.

${ }^{\mathrm{b}}$ Status quo levels are printed bold.

${ }^{c}$ Variable omitted in the model. Value in the choice sets given by 74 (percentage of undeveloped land) minus the sum of the areas (attribute levels) of all other land uses combined. 
Table 2. Income, employment in the agricultural sector and past voting behavior of the sampled populations

\begin{tabular}{|c|c|c|c|c|c|}
\hline & \multirow{2}{*}{$\begin{array}{l}\text { Urban } \\
\text { Zurich }\end{array}$} & \multicolumn{2}{|c|}{ Periurban } & \multicolumn{2}{|c|}{ Rural } \\
\hline & & Faellanden & Greifensee & Grueningen & Baeretswil \\
\hline $\begin{array}{l}\text { Mean taxable income (1000 } \\
\text { SFR) }{ }^{a}\end{array}$ & 52.0 & 66.8 & 61.5 & 56.0 & 51.3 \\
\hline $\begin{array}{l}\text { Employment in agricultural } \\
\text { sector }(\%)^{a}\end{array}$ & 0.1 & 3.6 & 1.4 & 15.4 & 21.4 \\
\hline $\begin{array}{l}\text { Approval of NHP proposal } \\
(\%)^{b}\end{array}$ & 65 & 60 & 57 & 51 & 45 \\
\hline $\begin{array}{l}\text { Approval difference } \\
\text { agricultural policy proposals } \\
1996 \text { and } 1995^{c}\end{array}$ & 47 & 42 & 44 & 26 & 28 \\
\hline $\begin{array}{l}\text { a Data } 1996 \text { (COS, 1999). } \\
{ }^{\mathrm{b}} \text { Percentage 'yes' in a } 1996 \text { ca } \\
\text { instalments to the cantonal fur } \\
\text { see Schläpfer and Hanley (200 } \\
{ }^{\mathrm{c}} \text { Differences between aggrega } \\
\text { referenda on new constitution } \\
\text { proposition was controversial } \\
\text { farmers were not clearly linke } \\
\text { explicitly made direct paymen } \\
\text { approved by a large majority }\end{array}$ & $\begin{array}{l}\text { mal refe } \\
\text { or natur } \\
\text { for a de } \\
\text { municif } \\
\text { rticles to } \\
\text { d reject } \\
\text { ith ecol } \\
\text { lepende }\end{array}$ & $\begin{array}{l}\text { ndum on a } \mathrm{C} \\
\text { and heritage } \\
\text { iption of the } \\
\text { ity-level) vo } \\
\text { eform agricu } \\
\text { in the vote) } \\
\text { ical services } \\
\text { on fulfilling }\end{array}$ & $\begin{array}{l}\text { HF } 10 \text { millio } \\
\text { protection (E } \\
\text { proposition. } \\
\text { ing returns } \\
\text { ltural policy. } \\
\text { nainly becau } \\
\text { The second } \\
\text { a set of ecolc }\end{array}$ & $\begin{array}{l}n \text { increase in } \\
\text { xecutive Cour } \\
\text { two consecu } \\
\text { The first (199 } \\
\text { se direct payn } \\
\text { (1996) propos } \\
\text { gical requiren }\end{array}$ & $\begin{array}{l}\text { the annual } \\
\text { cil, 1996b); } \\
\text { tive national } \\
\text { 5) } \\
\text { nents to } \\
\text { sition } \\
\text { nents and was }\end{array}$ \\
\hline
\end{tabular}


Table 3. Experimental design with stratification by populations

\begin{tabular}{lcc}
\hline Stratification & \multicolumn{2}{c}{ Information treatment } \\
\cline { 2 - 3 } & Party information (INFO=1) & No party information (INFO=0) \\
\hline Urban & $66(501)$ & $72(520)$ \\
Periurban (Periurban=1) & $92(666)$ & $97(678)$ \\
Rural (Rural=1) & $103(736)$ & $111(752)$ \\
\hline Note: Entries are number of respondents and number of choices (in parentheses).
\end{tabular}


Table 4. Frequency of the party positions "alternative", "status quo" and "no recommendation" for the six political parties and interest groups

\begin{tabular}{lccc}
\hline Party or interest group & Alternative & Status quo & No recommendation \\
\hline People's Party & 5 & 35 & 0 \\
Christian Democrats & 6 & 34 & 0 \\
Social Democrats & 16 & 24 & 0 \\
Swiss Consumer Forum & 15 & 25 & 0 \\
Pro Natura & 31 & 4 & 5 \\
Swiss Farmers Union & 5 & 27 & 8 \\
\hline
\end{tabular}


Table 5. Participation rates

\begin{tabular}{lcccccccc}
\hline & \multicolumn{2}{c}{ Total } & \multicolumn{2}{c}{ Urban } & \multicolumn{2}{c}{ Periurban } & \multicolumn{2}{c}{ Rural } \\
\cline { 2 - 8 } & Number & Percent & Number & Percent & Number & Percent & Number & Percent \\
\hline $\begin{array}{l}\text { Initial addresses } \\
\begin{array}{l}\text { Recruited } \\
\text { individuals }\end{array}\end{array}$ & 1860 & 100.0 & 620 & 100.0 & 620 & 100 & 620 & 100.0 \\
\hline $\begin{array}{l}\text { Questionnaires } \\
\text { distributed }\end{array}$ & 782 & 42.0 & 210 & 33.9 & 283 & 45.6 & 289 & 46.6 \\
$\begin{array}{l}\text { Questionnaires } \\
\text { returned }\end{array}$ & 546 & 69.8 & 143 & 68.1 & 189 & 66.8 & 214 & 74.0 \\
\hline
\end{tabular}


Table 6. Statistical comparison of respondent characteristics between the experimental treatments (subsamples with and without party information)

\begin{tabular}{|c|c|c|c|}
\hline Variable & Description & $\begin{array}{l}\text { Descriptive } \\
\text { statistics }^{\text {a }}\end{array}$ & $\begin{array}{l}\text { Test } \\
\text { statistic }^{b}\end{array}$ \\
\hline Age & $\begin{array}{l}\text { Categories: } 1=\text { less than } 20 ; 2=20-29 ; 3=30-39 ; \ldots \\
7=70 \text { or above. }\end{array}$ & $\begin{array}{c}4.62 \\
(1.55) \\
\mathrm{n}=517\end{array}$ & $\chi_{<6>}^{2}=2.05$ \\
\hline Gender & Binary variable: $0=$ male; $1=$ female & $\begin{array}{l}0.54 \\
(0.50) \\
\mathrm{n}=516\end{array}$ & $\chi^{2}<1>=0.0$ \\
\hline Education & $\begin{array}{l}\text { Categories for educational level: ranging from } 1= \\
\text { mandatory schooling only to } 5=\text { college or } \\
\text { university degree. }\end{array}$ & $\begin{array}{l}3.09 \\
(1.32) \\
\mathrm{n}=512\end{array}$ & $\chi^{2}<4>=4.47$ \\
\hline Residency & $\begin{array}{l}\text { Length of residency in the Canton of Zurich (in } \\
\text { years). }\end{array}$ & $\begin{array}{l}39.1 \\
(18.2) \\
\mathrm{n}=511\end{array}$ & $\mathrm{t}_{<1>}=0.48$ \\
\hline Tax bill & $\begin{array}{l}\text { Continuous variable for total annual individual } \\
\text { direct tax payments }(\mathrm{CHF}) \text {. }\end{array}$ & $\begin{array}{c}9347 \\
(16,722) \\
n=477\end{array}$ & $\mathrm{t}_{<1>}=0.25$ \\
\hline Attitude & $\begin{array}{l}\text { Categories for preferred level of cantonal } \\
\text { expenditures for nature and landscape protection } \\
\text { relative to current level: } 1=\text { less; } 2=\text { rather less; } 3= \\
\text { same amount; } 4=\text { rather more; } 5=\text { more. }\end{array}$ & $\begin{array}{l}3.62 \\
(0.98) \\
\mathrm{n}=478\end{array}$ & $\chi^{2}<4>=2.98$ \\
\hline
\end{tabular}

${ }^{\mathrm{a}}$ The descriptive statistics for each variable are mean, standard deviation, and sample size.

${ }^{b}$ Test statistic for the null hypotheses that the distributions of responses are the same, with degrees of freedom (two-sided test). 
Table 7. Frequency of responses by population and information treatment and test results for split-sample comparison

\begin{tabular}{|c|c|c|c|c|c|c|c|}
\hline \multicolumn{2}{|c|}{ Population Treatment split } & \multicolumn{4}{|c|}{ Frequency of responses } & \multirow{2}{*}{$\begin{array}{l}\chi^{2}<3> \\
\text { statistic }\end{array}$} & \multirow{2}{*}{$\begin{array}{l}\chi^{2}<1> \\
(\mathrm{A}+\mathrm{B} v s . \\
\text { other })\end{array}$} \\
\hline & samples tested & $\mathrm{A}$ & B & $\begin{array}{l}\text { "No } \\
\text { choice" }\end{array}$ & $\begin{array}{l}\text { Non- } \\
\text { response }\end{array}$ & & \\
\hline \multirow[t]{2}{*}{ Urban } & INFO & 255 & 246 & 11 & 16 & $33.1 * * *$ & $8.08 * * *$ \\
\hline & Control & 262 & 258 & 30 & 66 & & \\
\hline \multirow[t]{2}{*}{ Periurban } & INFO & 321 & 345 & 46 & 24 & $15.8 * * *$ & $3.71 *$ \\
\hline & Control & 295 & 383 & 41 & 57 & & \\
\hline \multirow[t]{2}{*}{ Rural } & INFO & 410 & 326 & 33 & 55 & $10.0^{* *}$ & $33.0 * * *$ \\
\hline & Control & 395 & 357 & 57 & 79 & & \\
\hline \multirow[t]{2}{*}{ Pooled } & INFO & 986 & 917 & 90 & 95 & $40.8 * * *$ & $32.5 * * *$ \\
\hline & Control & 952 & 998 & 128 & 202 & & \\
\hline
\end{tabular}


Table 8. Random-effects Probit estimates for the six information $\times$ population subsamples

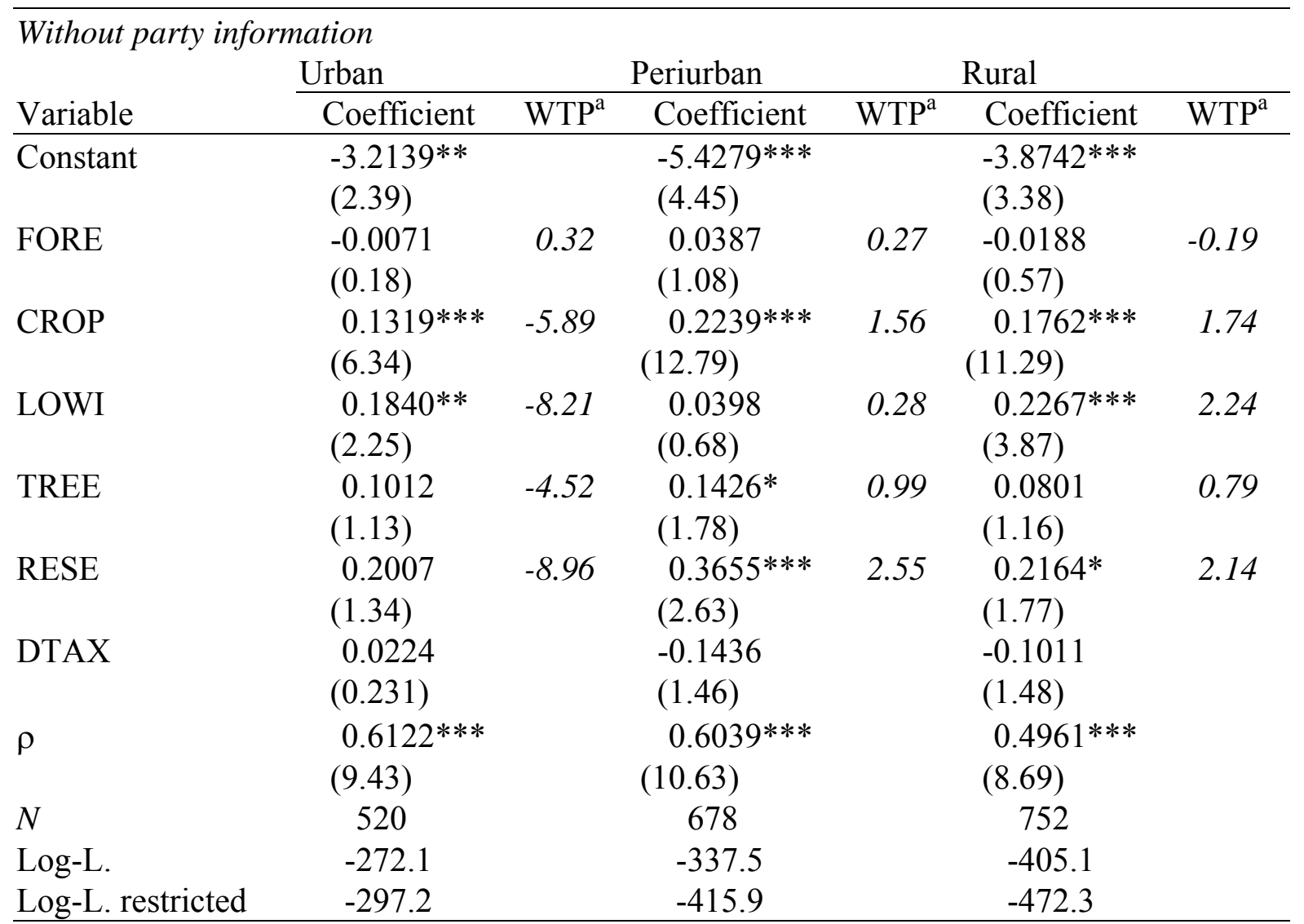

With party information

\begin{tabular}{lllllll} 
& \multicolumn{2}{c}{ Urban } & \multicolumn{2}{c}{ Periurban } & Rural \\
\cline { 2 - 6 } Constant & Coefficient & WTP $^{\mathrm{a}}$ & Coefficient & WTP $^{\mathrm{a}}$ & Coefficient & WTP $^{\mathrm{a}}$ \\
& $-5.1278^{* * *}$ & & $-3.2511^{* * *}$ & & -1.5855 & \\
FORE & $(3.78)$ & & $(2.66)$ & & $(1.40)$ & \\
& 0.0020 & 0.01 & -0.0312 & -0.17 & $-0.1120^{* * *}$ & -0.72 \\
CROP & $(0.05)$ & & $(0.85)$ & & $(3.12)$ & \\
& $0.1750^{* * *}$ & 1.27 & $0.1803^{* * *}$ & 0.97 & $0.2066^{* * *}$ & 1.33 \\
LOWI & $(8.03)$ & & $(10.99)$ & & $(10.49)$ & \\
& $0.2338^{* * *}$ & \multirow{2}{*}{1.69} & $0.1485^{* *}$ & 0.80 & $0.1609 * *$ & 1.04 \\
TREE & $(3.21)$ & & $(2.31)$ & & $(2.39)$ & \\
& $0.2164 * *$ & 1.57 & 0.0920 & 0.50 & 0.1461 & 0.94 \\
RESE & $(2.56)$ & & $(1.29)$ & & $(1.59)$ & \\
& $0.2705^{*}$ & 1.96 & $0.3206^{* * *}$ & 1.73 & $0.2044 *$ & 1.32 \\
DTAX & $(1.63)$ & & $(2.84)$ & & $(1.74)$ & \\
& -0.1382 & & $-0.1852^{* *}$ & & $-0.1552^{* *}$ & \\
$\rho$ & $(1.56)$ & & $(2.37)$ & & $(2.02)$ & \\
& $0.5452^{* * *}$ & & $0.4718^{* * *}$ & & $0.6073 * * *$ & \\
$N$ & $(7.66)$ & & $(7.60)$ & & $(0.0574)$ & \\
Log-L. & 501 & & 666 & & 736 & \\
Log-L. restricted & -261.7 & & -360.5 & & -363.4 & \\
\hline
\end{tabular}

Notes: t-statistics in parentheses; significance levels, see Table 7.

${ }^{\mathrm{a}} \mathrm{WTP}$ is the willingness-to-pay (in tax percentages) computed as $b_{\mathrm{X}} /-b_{\mathrm{DTAX}}$. Values computed from non-significant coefficients in italics. 
Table 9. Experimental designs with alternative stratifications of the sample

\begin{tabular}{lcc}
\hline & \multicolumn{2}{c}{ Information treatment } \\
\cline { 2 - 3 } Stratification & $\begin{array}{c}\text { Party } \\
\text { information } \\
\text { (INFO=1) }\end{array}$ & $\begin{array}{c}\text { No party } \\
\text { information } \\
\text { (INFO=0) }\end{array}$ \\
\hline $\begin{array}{l}\text { by attitude towards spending for nature and landscape } \\
\text { "Spend (rather) more" (Attitude=1) }\end{array}$ & $135(1052)$ & $133(975)$ \\
Other responses (Attitude=0) & $112(851)$ & $133(975)$ \\
\hline by annual tax bill & & \\
$<4000 \mathrm{CHF}$ & $72(565)$ & $87(638)$ \\
4001 to 8000 CHF & $93(712)$ & $71(535)$ \\
$>8000 \mathrm{CHF}$ & $74(564)$ & $80(611)$ \\
\hline
\end{tabular}

Note: Entries are number of respondents and number of choices (in parentheses). 
Table 10. Probit estimates for the individual choice sets.

\begin{tabular}{|c|c|c|c|c|c|c|c|c|c|c|c|c|c|c|c|c|}
\hline \multirow[b]{2}{*}{ Policy } & \multicolumn{6}{|c|}{ Policy characteristics } & \multicolumn{2}{|c|}{ Constant } & \multicolumn{2}{|c|}{ INFO } & \multicolumn{2}{|c|}{ INFO $\times$ Attitude } & \multicolumn{2}{|c|}{ INFO $\times$ Education } & \multirow[b]{2}{*}{$\mathrm{N}$} & \multirow[b]{2}{*}{$\%$ yes $^{b}$} \\
\hline & FORE & CROP & LOWI & $\mathrm{ORCH}$ & RESE & DTAX & Coeff. & t-ratio & Coeff. $^{\mathrm{a}}$ & t-ratio & Coeff. $^{\mathrm{a}}$ & t-ratio & Coeff. $^{a}$ & t-ratio & & \\
\hline $\mathrm{SQ}^{\mathrm{c}}$ & 28 & 18 & 4 & 3 & 1 & 0 & - & & - & & - & & - & & - & - \\
\hline 1 & 28 & 14 & 6 & 4 & 2 & -1 & 0.450 & 2.42 & $-4.326^{* *}$ & -2.43 & $1.205^{* * *}$ & 2.81 & -0.045 & -0.22 & 86 & 66 \\
\hline 2 & 30 & 14 & 4 & 5 & 1 & -2 & 0.084 & 0.45 & 0.311 & 0.25 & 0.381 & 1.48 & -0.320 & -1.51 & 81 & 63 \\
\hline 3 & 32 & 18 & 6 & 3 & 2 & 0 & 0.298 & 1.60 & $-3.679 * * *$ & -2.75 & $0.682 * *$ & 2.55 & $0.396 *$ & 1.93 & 84 & 62 \\
\hline 4 & 28 & 10 & 4 & 5 & 2 & -1 & -0.641 & -3.22 & -2.044 & -1.48 & 0.430 & 1.53 & 0.155 & 0.82 & 80 & 28 \\
\hline 5 & 32 & 18 & 4 & 4 & 2 & -1 & 0.431 & 2.30 & $-3.716 * *$ & -2.53 & $0.908 * * *$ & 2.77 & 0.103 & 0.54 & 85 & 66 \\
\hline 6 & 28 & 10 & 6 & 5 & 1 & 0 & -0.512 & -2.64 & -1.479 & -1.01 & 0.517 & 1.64 & -0.196 & -1.05 & 82 & 29 \\
\hline 7 & 32 & 10 & 6 & 3 & 1 & -1 & -0.641 & -3.22 & $-4.385 * *$ & -2.41 & $1.014 * * *$ & 2.64 & 0.134 & 0.69 & 82 & 27 \\
\hline 8 & 28 & 10 & 6 & 5 & 2 & -2 & -0.311 & -1.64 & -2.096 & -1.64 & $0.607 * *$ & 2.20 & 0.123 & 0.63 & 79 & 47 \\
\hline 9 & 28 & 18 & 6 & 3 & 1 & -2 & 0.951 & 4.11 & $-2.166^{*}$ & -1.80 & $0.515^{*}$ & 1.83 & -0.002 & -0.01 & 84 & 79 \\
\hline 10 & 30 & 18 & 4 & 5 & 2 & 0 & 0.586 & 2.88 & $-2.614 * *$ & -2.20 & 0.420 & 1.59 & 0.237 & 1.54 & 86 & 66 \\
\hline 11 & 30 & 14 & 6 & 5 & 2 & -1 & 0.518 & 2.58 & $-3.728 * * *$ & -2.79 & $0.746^{* *}$ & 2.54 & 0.132 & 0.84 & 85 & 60 \\
\hline 12 & 32 & 10 & 4 & 4 & 1 & 0 & -0.805 & -3.51 & -2.140 & -0.99 & 0.102 & 0.23 & 0.354 & 1.32 & 80 & 15 \\
\hline 13 & 32 & 10 & 6 & 3 & 2 & -2 & -0.279 & -1.40 & -1.430 & -1.11 & 0.330 & 1.18 & -0.067 & -0.41 & 84 & 32 \\
\hline 14 & 28 & 10 & 4 & 4 & 2 & 0 & -0.755 & -3.43 & -0.620 & -0.47 & 0.100 & 0.34 & 0.071 & 0.40 & 81 & 22 \\
\hline 15 & 32 & 14 & 4 & 5 & 2 & -2 & 0.637 & 3.06 & $-3.000 * *$ & -2.41 & $0.491 *$ & 1.79 & 0.156 & 1.04 & 85 & 61 \\
\hline 16 & 32 & 10 & 4 & 5 & 1 & -1 & -0.618 & -2.94 & 0.022 & 0.02 & -0.091 & -0.30 & -0.048 & -0.27 & 84 & 20 \\
\hline 17 & 28 & 18 & 6 & 5 & 2 & 0 & 0.656 & 3.17 & -0.127 & -0.11 & 0.091 & 0.37 & 0.065 & 0.32 & 86 & 80 \\
\hline 18 & 30 & 18 & 6 & 3 & 2 & -2 & 0.805 & 3.51 & $-1.846^{*}$ & -1.73 & 0.112 & 0.49 & $0.406 * *$ & 2.09 & 81 & 77 \\
\hline 19 & 28 & 18 & 4 & 4 & 1 & -1 & 0.899 & 3.81 & -1.287 & -1.13 & 0.126 & 0.50 & 0.290 & 1.41 & 81 & 82 \\
\hline 20 & 32 & 14 & 6 & 4 & 1 & 0 & 0.336 & 1.62 & $-2.086 * *$ & -2.08 & 0.226 & 1.13 & $0.307^{*}$ & 1.76 & 79 & 59 \\
\hline
\end{tabular}


(Table 10 continued)

\begin{tabular}{|c|c|c|c|c|c|c|c|c|c|c|c|c|c|c|c|c|}
\hline \multirow[b]{2}{*}{ Policy } & \multicolumn{6}{|c|}{ Policy characteristics } & \multicolumn{2}{|c|}{ Constant } & \multicolumn{2}{|c|}{ INFO } & \multicolumn{2}{|c|}{ INFO $\times$ attitude } & \multicolumn{2}{|c|}{ INFO $\times$ education } & \multirow[b]{2}{*}{$\mathrm{N}$} & \multirow[b]{2}{*}{$\%$ yes $^{b}$} \\
\hline & FORE & CROP & LOWI & ORCH & RESE & DTAX & Coeff. & t-ratio & Coeff. $^{a}$ & t-ratio & Coeff. $^{a}$ & t-ratio & Coeff. $^{\text {a }}$ & t-ratio & & \\
\hline 22 & 28 & 10 & 6 & 3 & 2 & 0 & -0.674 & -2.97 & -1.078 & -1.02 & 0.290 & 1.41 & 0.011 & 0.07 & 79 & 27 \\
\hline 24 & 30 & 14 & 4 & 3 & 1 & 0 & -0.842 & -3.48 & 0.936 & 0.88 & -0.150 & -0.69 & -0.097 & -0.53 & 76 & 21 \\
\hline 25 & 28 & 18 & 4 & 5 & 2 & -2 & 0.730 & 3.46 & $-1.608^{*}$ & -1.80 & 0.260 & 1.28 & 0.305 & 1.61 & 91 & 78 \\
\hline 26 & 28 & 14 & 4 & 5 & 1 & 0 & 0.084 & 0.45 & $-1.788 * *$ & -2.17 & 0.276 & 1.25 & -0.020 & -0.11 & 91 & 38 \\
\hline 27 & 32 & 18 & 6 & 5 & 1 & -1 & 0.172 & 0.90 & $-2.959 * * *$ & -3.46 & $0.364 *$ & 1.93 & $0.564 * * *$ & 3.34 & 93 & 55 \\
\hline 30 & 30 & 18 & 6 & 3 & 1 & 0 & 0.605 & 2.99 & $-2.573 * * *$ & -3.10 & $0.327^{*}$ & 1.74 & $0.396^{* *}$ & 2.35 & 91 & 67 \\
\hline 31 & 32 & 10 & 4 & 4 & 2 & -2 & -0.303 & -1.54 & $-2.197 * * *$ & -2.61 & $0.323 *$ & 1.71 & $0.313^{*}$ & 1.91 & 89 & 36 \\
\hline 32 & 32 & 14 & 4 & 3 & 2 & 0 & 0.196 & 1.04 & $-2.348 * * *$ & -2.86 & $0.534 * *$ & 2.56 & 0.097 & 0.60 & 93 & 55 \\
\hline 33 & 28 & 18 & 6 & 5 & 1 & -2 & 0.566 & 2.98 & -1.541 & -1.18 & 0.439 & 1.55 & 0.129 & 0.69 & 98 & 78 \\
\hline 34 & 32 & 18 & 4 & 3 & 1 & -2 & 0.188 & 1.02 & -1.026 & -0.95 & 0.224 & 0.96 & 0.098 & 0.67 & 96 & 59 \\
\hline 35 & 30 & 10 & 6 & 4 & 2 & 0 & -0.055 & -0.29 & -1.629 & -1.42 & 0.381 & 1.52 & -0.001 & -0.01 & 92 & 43 \\
\hline 40 & 30 & 10 & 6 & 4 & 1 & -2 & 0.055 & 0.29 & $-3.766 * * *$ & -2.90 & $0.751 * * *$ & 2.62 & 0.229 & 1.47 & 94 & 47 \\
\hline
\end{tabular}

${ }^{a}$ Significance levels: see Table 7.

${ }^{\mathrm{b}}$ Percentage yes to alternative policy (vs. status quo).

${ }^{\mathrm{c}}$ Status quo policy.

${ }^{\mathrm{d}}$ Estimates unreliable; data distribution does not satisfy model assumptions. 
Table 11. Random-effects Probit estimates for the four information $\times$ attitude subsamples

\begin{tabular}{|c|c|c|c|c|c|c|c|c|}
\hline & \multicolumn{4}{|c|}{ Without party information } & \multicolumn{4}{|c|}{ With party information } \\
\hline & \multicolumn{2}{|c|}{$\begin{array}{c}\text { Attitude }=1 \text { (spend } \\
\text { more) }\end{array}$} & \multicolumn{2}{|c|}{$\begin{array}{l}\text { Attitude }=0 \text { (other } \\
\text { responses) }\end{array}$} & \multicolumn{2}{|c|}{$\begin{array}{c}\text { Attitude }=1 \text { (spend } \\
\text { more) }\end{array}$} & \multicolumn{2}{|c|}{$\begin{array}{c}\text { Attitude }=0 \text { (other } \\
\text { responses) }\end{array}$} \\
\hline & Coefficient & WTP $^{a}$ & Coefficient & $\mathrm{WTP}^{\mathrm{a}}$ & Coefficient & WTP $^{a}$ & Coefficient & WTP $^{\mathrm{a}}$ \\
\hline Constant & $\begin{array}{l}-4.8450 * * * \\
(-4.81)\end{array}$ & & $\begin{array}{l}-3.5313 * * * \\
(-3.69)\end{array}$ & & $\begin{array}{l}-5.2592 * * * \\
(-5.24)\end{array}$ & & $\begin{array}{l}-0.6555 \\
(-0.66)\end{array}$ & \\
\hline FORE & $\begin{array}{l}0.0038 \\
(0.13)\end{array}$ & 0.06 & $\begin{array}{l}-0.0026 \\
(-0.09)\end{array}$ & -0.02 & $\begin{array}{l}-0.0071 \\
(-0.24)\end{array}$ & -0.05 & $\begin{array}{l}-0.1066 * * * \\
(-3.30)\end{array}$ & -0.57 \\
\hline CROP & $\begin{array}{l}0.2008^{* * *} \\
(14.07)\end{array}$ & 3.37 & $\begin{array}{l}0.1599 * * * \\
(12.21)\end{array}$ & 1.43 & $\begin{array}{l}0.2035^{* * *} \\
(15.57)\end{array}$ & 1.43 & $\begin{array}{l}0.1732 * * * \\
(9.30)\end{array}$ & 0.93 \\
\hline LOWI & $\begin{array}{l}0.1460 * * * \\
(2.97)\end{array}$ & 2.45 & $\begin{array}{l}0.1727 * * * \\
(3.16)\end{array}$ & 1.54 & $\begin{array}{l}0.3019 * * * \\
(6.02)\end{array}$ & 2.12 & $\begin{array}{l}0.0248 \\
(0.40)\end{array}$ & 0.13 \\
\hline $\mathrm{ORCH}$ & $\begin{array}{l}0.2457 * * * \\
(3.77)\end{array}$ & 4.13 & $\begin{array}{l}-0.0187 \\
(-0.31)\end{array}$ & -0.17 & $\begin{array}{l}0.1789 * * * \\
(2.94)\end{array}$ & 1.25 & $\begin{array}{l}0.1115 \\
(1.50)\end{array}$ & 0.60 \\
\hline RESE & $\begin{array}{l}0.3473 * * * \\
(3.10)\end{array}$ & 5.83 & $\begin{array}{l}0.1805^{*} \\
(1.69)\end{array}$ & 1.61 & $\begin{array}{l}0.3460 * * * * \\
(3.40)\end{array}$ & 2.42 & $\begin{array}{l}0.1616 \\
(1.45)\end{array}$ & 0.87 \\
\hline DTAX & $\begin{array}{l}-0.0595 \\
(-0.82)\end{array}$ & & $\begin{array}{l}-0.1120^{*} \\
(-1.73)\end{array}$ & & $\begin{array}{l}-0.1428^{* *} \\
(-2.38)\end{array}$ & & $\begin{array}{l}-0.1866^{* *} \\
(-2.43)\end{array}$ & \\
\hline Rho & $\begin{array}{l}0.5403 * * * \\
(10.89)\end{array}$ & & $\begin{array}{l}0.5793^{* * *} \\
(12.08)\end{array}$ & & $\begin{array}{l}0.4803 * * * \\
(9.54)\end{array}$ & & $\begin{array}{l}0.5764 * * * \\
(10.78)\end{array}$ & \\
\hline$N$ & 975 & & 975 & & 1052 & & 851 & \\
\hline Log-1. & -491.4 & & -521.8 & & -541.2 & & -428 & \\
\hline Log-1. restr. & -582.8 & & -625.8 & & -616.4 & & -517 & \\
\hline
\end{tabular}

Notes: t-statistics in parentheses; significance levels, see Table 7.

${ }^{\mathrm{a}} \mathrm{WTP}$ is the willingness-to-pay (in tax percentages) computed as $b_{\mathrm{X}} /-b_{\mathrm{DTAX}}$. Values computed from non-significant coefficients in italics. 
Table 12. Random-effects Probit model including the interactions of the policy attributes with INFO and Attitude (pooled samples)

\begin{tabular}{|c|c|c|}
\hline Variable & Coefficient & $t$-statistic ${ }^{\text {a }}$ \\
\hline Constant & $-3.6835 * * *$ & -7.58 \\
\hline FORE & 0.0033 & 0.19 \\
\hline CROP & $0.1568 * * *$ & 12.43 \\
\hline LOWI & $0.1715^{* * *}$ & 3.28 \\
\hline $\mathrm{ORCH}$ & -0.0128 & -0.22 \\
\hline RESE & $0.1825^{*}$ & 1.74 \\
\hline DTAX & $-0.1106^{*}$ & -1.73 \\
\hline FORE $\times$ INFO & -0.0271 & -1.30 \\
\hline $\mathrm{CROP} \times \mathrm{INFO}$ & 0.0183 & 0.86 \\
\hline LOWI $\times$ INFO & -0.1053 & -1.35 \\
\hline $\mathrm{ORCH} \times \mathrm{INFO}$ & $0.1699 *$ & 1.89 \\
\hline $\mathrm{RESE} \times \mathrm{INFO}$ & 0.0281 & 0.18 \\
\hline DTAX $\times$ INFO & -0.0971 & -0.99 \\
\hline FORE $\times$ Attitude & $-0.0291 *$ & -1.75 \\
\hline $\mathrm{CROP} \times$ Attitude & $0.0420 * *$ & 2.28 \\
\hline LOWI $\times$ Attitude & -0.0435 & -0.61 \\
\hline $\mathrm{ORCH} \times$ Attitude & $0.2348 * * *$ & 2.77 \\
\hline RESE $\times$ Attitude & 0.1404 & 0.94 \\
\hline DTAX $\times$ Attitude & 0.0590 & 0.61 \\
\hline FORE $\times$ INFO $\times$ Attitude & 0.0019 & 0.07 \\
\hline $\mathrm{CROP} \times \mathrm{INFO} \times$ Attitude & -0.0115 & -0.41 \\
\hline LOWI $\times$ INFO $\times$ Attitude & $0.2589 * *$ & 2.49 \\
\hline $\mathrm{ORCH} \times \mathrm{INFO} \times$ Attitude & -0.2390 & -1.94 \\
\hline RESE $\times$ INFO $\times$ Attitude & -0.0321 & -0.15 \\
\hline DTAX $\times$ INFO $\times$ Attitude & 0.0131 & 0.10 \\
\hline$\rho$ & $0.5406^{* * *}$ & 21.53 \\
\hline$N$ & \multicolumn{2}{|c|}{3853} \\
\hline Log-likelihood & \multicolumn{2}{|c|}{-1989.9} \\
\hline Log-likelihood restricted & \multicolumn{2}{|c|}{-2346.5} \\
\hline
\end{tabular}

Note: Significance levels: see Table 7. 
Table 13. Random-effects Probit estimates for six information $\times$ tax-bill subsamples

\begin{tabular}{|c|c|c|c|c|c|c|}
\hline \multicolumn{7}{|c|}{ Without party information } \\
\hline \multirow[b]{2}{*}{ Variable } & \multicolumn{2}{|c|}{ Tax bill $<4000$} & \multicolumn{2}{|c|}{ Tax bill 4001-8000 } & \multicolumn{2}{|c|}{ Tax bill $>8000$} \\
\hline & Coefficient & WTP & Coefficient & WTP & Coefficient & WTP \\
\hline Constant & $\begin{array}{l}-2.1147^{*} \\
(1.70)\end{array}$ & & $\begin{array}{l}-5.1533 * * * \\
(3.66)\end{array}$ & & $\begin{array}{l}-6.7422 * * * \\
(4.57)\end{array}$ & \\
\hline FORE & $\begin{array}{l}-0.0239 \\
(0.61)\end{array}$ & -0.29 & $\begin{array}{l}0.0060 \\
(0.15)\end{array}$ & 0.09 & $\begin{array}{l}0.0597 \\
(1.52)\end{array}$ & 1.85 \\
\hline CROP & $\begin{array}{l}0.1728^{* * *} \\
(11.02)\end{array}$ & 2.08 & $\begin{array}{l}0.1934 * * * \\
(9.52)\end{array}$ & 2.94 & $\begin{array}{l}0.1982 * * * \\
(10.97)\end{array}$ & 6.13 \\
\hline LOWI & $\begin{array}{l}0.0438 \\
(0.79)\end{array}$ & 0.53 & $\begin{array}{l}0.2158^{* * * *} \\
(2.60)\end{array}$ & 3.29 & $\begin{array}{l}0.2305 * * * \\
(3.08)\end{array}$ & 7.13 \\
\hline TREE & $\begin{array}{l}0.0038 \\
(0.05)\end{array}$ & 0.05 & $\begin{array}{l}0.1910^{* *} \\
(2.06)\end{array}$ & 2.91 & $\begin{array}{l}0.2095 * * \\
(2.46)\end{array}$ & 6.48 \\
\hline RESE & $\begin{array}{l}0.1067 \\
(0.82)\end{array}$ & 1.28 & $\begin{array}{l}0.2334 \\
(1.44)\end{array}$ & 3.55 & $\begin{array}{l}0.2865^{* *} \\
(2.01)\end{array}$ & 8.86 \\
\hline DTAX & $\begin{array}{l}-0.0832 \\
(1.05)\end{array}$ & & $\begin{array}{l}-0.0657 \\
(0.59)\end{array}$ & & $\begin{array}{l}-0.0323 \\
(0.38)\end{array}$ & \\
\hline$\rho$ & $\begin{array}{l}0.4408^{* * * *} \\
(6.93)\end{array}$ & & $\begin{array}{l}0.6799 * * * \\
(11.73)\end{array}$ & & $\begin{array}{l}0.5532 \\
(8.82)\end{array}$ & \\
\hline$N$ & 638 & & 535 & & 611 & \\
\hline Log-L. & -359.8 & & -258.4 & & -314.2 & \\
\hline Log-L. restricted & -402.3 & & -340.9 & & -373.0 & \\
\hline
\end{tabular}

\begin{tabular}{|c|c|c|c|c|c|c|}
\hline \multirow[b]{2}{*}{ Variable } & \multicolumn{2}{|c|}{ Tax bill $<4000$} & \multicolumn{2}{|c|}{ Tax bill 4001-8000 } & \multicolumn{2}{|c|}{ Tax bill $>8000$} \\
\hline & Coefficient & WTP & Coefficient & WTP & Coefficient & WTP \\
\hline Constant & -1.8137 & & $-3.5785 * * *$ & & $-3.5554 * *$ & \\
\hline FORE & -0.0663 & -0.82 & $-0.0648 *$ & -0.27 & -0.0499 & -0.18 \\
\hline CROP & $\begin{array}{l}0.1617 * * * \\
(7.46)\end{array}$ & 2.00 & $\begin{array}{l}0.2087 * * * \\
(10.76)\end{array}$ & 0.87 & $\begin{array}{l}0.1970 * * * \\
(10.45)\end{array}$ & 0.71 \\
\hline LOWI & $\begin{array}{l}0.1295^{*} \\
(1.91)\end{array}$ & 1.61 & $\begin{array}{l}0.2181 * * * \\
(3.20)\end{array}$ & 0.91 & $\begin{array}{l}0.2391 * * * \\
(3.01)\end{array}$ & 0.86 \\
\hline TREE & $\begin{array}{l}0.1542 * \\
(2.01)\end{array}$ & 1.91 & $\begin{array}{l}0.1520^{*} \\
(1.88)\end{array}$ & 0.64 & $\begin{array}{l}0.1609 * \\
(1.69)\end{array}$ & 0.58 \\
\hline RESE & $\begin{array}{l}0.0198 \\
(0.16)\end{array}$ & 0.25 & $\begin{array}{l}0.4210 * * * \\
(3.20)\end{array}$ & 1.76 & $\begin{array}{l}0.2239 \\
(1.40)\end{array}$ & 0.81 \\
\hline DTAX & $\begin{array}{l}-0.0806 \\
(1.04)\end{array}$ & & $\begin{array}{l}-0.2387 * * * \\
(2.94)\end{array}$ & & $\begin{array}{l}-0.2767 * * * \\
(2.70)\end{array}$ & \\
\hline$\rho$ & $\begin{array}{l}0.4673 * * * \\
(6.70)\end{array}$ & & $\begin{array}{l}0.5867 * * * \\
(10.52)\end{array}$ & & $\begin{array}{l}0.5993 * * * \\
(9.58)\end{array}$ & \\
\hline$N$ & 565 & & 712 & & 564 & \\
\hline Log-L. & -312.2 & & -352.0 & & -279.5 & \\
\hline Log-L. restricted & -352.9 & & -429.4 & & -339.9 & \\
\hline
\end{tabular}

Notes: See Table 8. 
Figure legends (Appendix)

Appendix Figure 1 Example of a choice set (translated from German).

Appendix Figure 2 Party and interest group positions (information shortcuts sheet for the 8 choice sets of Block 1; translated from German). 
Example

Forest

High-intensity grassland

Crop land

Low-intensity meadows

Orchards, hedgerows

Nature reserves

My tax bill will be ...
Landscape A (Alternative)

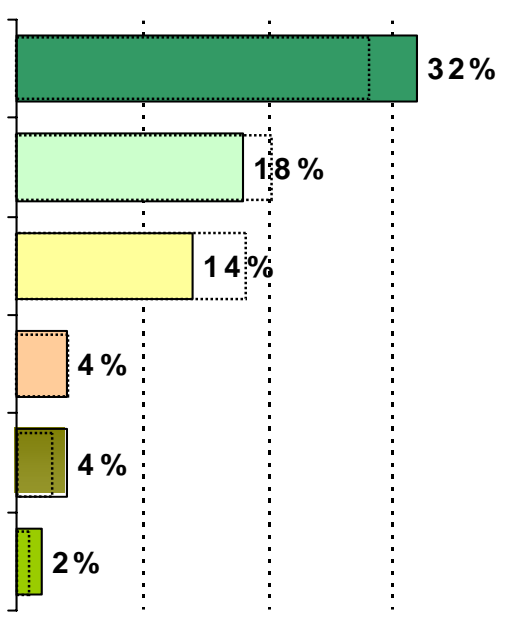

1 percent less

(corresponding in my case to
Landscape B (Status Quo)

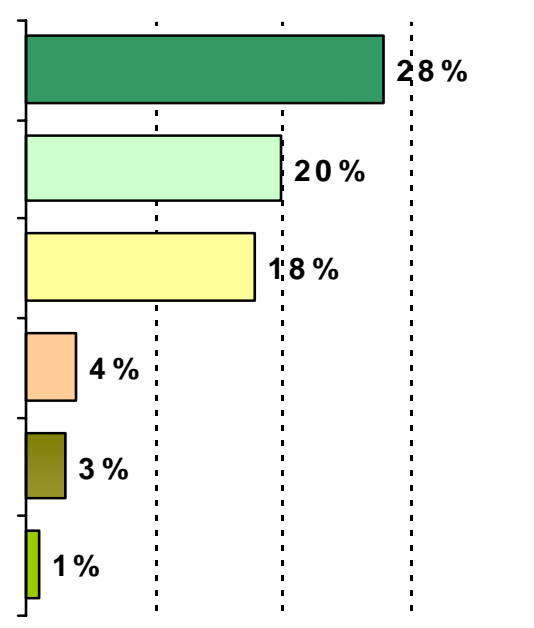

unchanged 


\section{Choice recommendations of parties and interest groups (enclosure with the questionnaire)}

In questions 2.1 to 2.8 the representatives of the listed parties and interest groups recommend you tick the following landscapes:

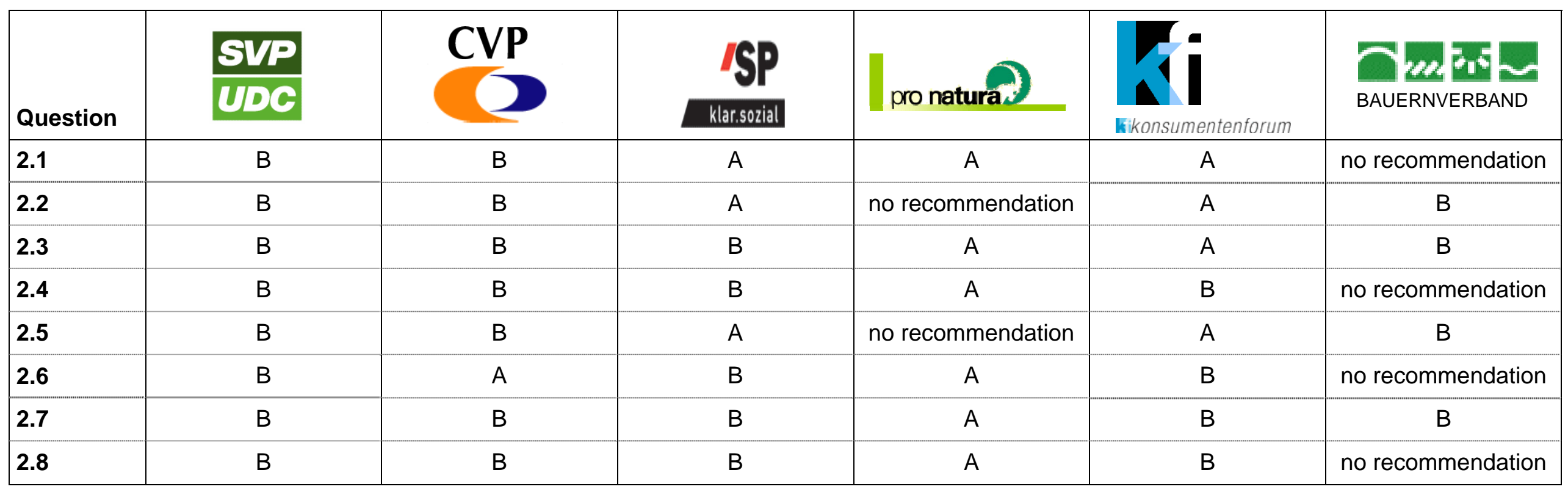

\section{Note:}

These recommendations do not necessarily correspond with the official opinion of the parties and interest groups. The "voting recommendations" originate from the following individuals who expressed the position of their party (or their interest group) regarding each future landscape development given:

SVP Jeannine Grünenfelder (scientific staff)

CVP Michela Trisconi (scientific staff)

SP Matthias Manz (policy field director)

Pro Natura: $\quad$ Pascale Aubert (project leader agriculture \& nature conservation); Ulrich Berchtold (project leader species- \& habitat protection)

Konsumentenforum: Marianne Cserhati-Hotz (President, Konsumentenforum Canton of Zurich)

Bauernverband: $\quad$ Marco Baltensweiler (head, section of agricultural economics); Mr. Baltensweiler gave the answer recommendations from of a long-term, future-oriented perspective 
